\title{
INFEKSI TOXOPLASMA PADA PENJUAL DAGING KAMBING DI PASAR TRADISIONAL SURABAYA
}

\author{
Oleh : \\ Yoso Wiyarno \\ (Tenaga Pengajar Fakultas Teknik Lingkungan Universitas PGRI Adi Buana Surabaya)
}

\begin{abstract}
ABSTRAK
Telah dilakukan penelitian infeksi Toxoplasma pada penjual daging di pasar tradisional Surabaya dengan menggunakan uji serologi untuk mengukur titer IgG antibodi terhadap Toxoplasma. Permasalahan penelitian adalah apakah terdapat perbedaan infeksi toksoplasmosis antara penjual daging kambing dengan bukan penjual daging berdasarkan titer Ig.G positif di pasar tradisional Surabaya? Subyek penelitian sebagai kelompok observasi adalah para penjual daging kambing di pasar tradisional Surabaya sebanyak 20 orang, sedangkan sebagai kontrol adalah bukan penjual daging di pasar tradisional Surabaya sebanyak 20 orang. Masing-masing subyek penelitian diambil sampel darah sebanyak $\pm 5 \mathrm{ml}$ yang selanjutnya dianalisis untuk diketahui besar titer $\mathrm{lgG}$ antibodi Toxoplasma dengan menggunakan teknik ELISA(Enzyme Linked Immunosorbent Assay). Hasil pemeriksaan diketahui yang positif toksoplasmosis berdasarkan besar titer lgG sebanyak 25 orang dan yang negatif toksoplasmosis sebanyak 15 orang. Data penelitian dianalisis dengan menggunakan uji statistik rumus chi-square dan didapatkan nilai p sebesar 0,022 yang berarti p. 0,022 $<0,05$ adalah signifikan. Hasil uji hipotesis menunjukkan bahwa hipotesis alternatif diterima. Simpulan penelitian terdapat perbedaan infeksi toksoplasmosis antara penjual daging kambing dengan bukan penjual daging berdasarkan titer Ig.G positif di pasar tradisional Surabaya. Saran: (1) perlu dilakukan peningkatan kesehatan dan keselamatan kerja di tempat pada penjual daging kambing dengan menggunakan APD (Alat Pelindung Diri) dan berperilaku sehat agar infeksi Toxoplasma yang terdapat pada daging kambing dapat dicegah; (2) perlu dilakukan perbaikan sarana yang terdapat di pasar tradisional Surabaya seperti tersedianya air bersih yang cukup, tempat sampah, cahaya dan ventilasi yang cukup; (3) Perlu dilakukan penyuluhan terhadap masyarakat agar berhati-hati jika kontak maupun mengolah daging kambing.
\end{abstract}

Kata Kunci : Infeksi Toxoplasma penjual daging kambing.

\section{PENDAHULUAN}

Toksoplasmosis adalah penyakit yang disebabkan Toxoplasma gondii yang dapat menimbulkan radang pada kulit, kelenjar getah bening, jantung, paru, otak, dan selaput otak (Soedarto, 1992; Sasmita, 1991). Toksoplasmosis umumnya bersifat asimtomatik, hanya sedikit yang benar-benar menunjukkan gejala sakit dan biasanya tidak terdiagnosis (Frenkel, 1990). Pada ibu hamil dan hewan bunting, infeksi yang berat dapat menyebabkan keguguran atau cacat kongenital pada anak yang dilahirkan. Penyakit ini sudah menyebar di seluruh dunia dan lebih sering terjadi pada daerah iklim panas dibandingkan dengan daerah iklim dingin (Shulman et al., 1994).

Dilihat dari segi kesehatan manusia, infeksi parasit ini juga dapat mengakibatkan abortus, kecacatan pada anak, ataupun kelainan lainnya seperti hidrosefalus, korioretinitis, kalsifikasi intrakranial bahkan kematian dari janin (Dachlan EG, 2006). Parasit Toxoplasma gondii ini merupakan golongan protozoa dan hidup di alam secara bebas serta bersifat parasit intraseluler obligat. Toxoplasma gondii pertama kali ditemukan pada limpa dan hati hewan pengerat (rodensia) Ctenodactyles gondii (gundi) di Sahara Afrika Utara (Sciammarella, 2001). Toxoplasma gondii termasuk dalam phylum Apicomplexa, kelas Sporozoa dan Subkelas Coccidia (Dubey, 1999). Parasit yang termasuk dalam phylum Apicomplexa mempunyai tiga karakteristik utama yaitu bersifat obligat intraseluler, mempunyai siklus hidup yang kompleks baik secara seksual ataupun aseksual dan mempunyai hospes yang bervariasi. Genus Toxoplasma hanya terdiri dari satu spesies yaitu Toxopasma gondii, parasit ini mempunyai sifat yang tidak umum dibandingkan dengan genus lain, di antaranya dapat menginfeksi hospes 
perantara dalam kisaran yang sangat luas (tidak bersifat hospes spesifik). Hospes perantara yang mudah terinfeksi antara lain adalah hewan berdarah panas, manusia, dan burung (Smith and Rebuck, 2000; Sciammarella, 2001).

Beberapa penelitian telah dilakukan pada binatang ternak yang dagingnya sering dikonsumsi oleh masyarakat luas yaitu kambing, babi, sapi, dan ayam. Penelitian Retnowulan (2004) mendapatkan insiden toksoplasmosis pada daging kambing di Surabaya $71 \%$; Kambing di RPH Surabaya dan Malang 33,33\% (Hartono, 1990); Kambing di daerah Tuban 20,6\% dan Kediri 20\% (Sasmita, 1993).

Hasil beberapa penelitian tersebut menjelaskan bahwa peranan kambing sangat penting dalam insiden toksoplasmosis di masyarakat. Hal tersebut disebabkan oleh tingkat konsumsi masyarakat terhadap daging kambing cukup tinggi, khususnya di Kota Surabaya.

Sumber penyebab tingginya insiden dan prevalensi toksoplasmosis meliputi banyak faktor dan cenderung kompleks. Hasil kajian di banyak negara menunjukkan bahwa intensitas kontak dengan kucing atau tingkat pencemaran media kehidupan atau makanan oleh kotoran kucing merupakan faktor utama (Mc.Cabe RE et al., 1995). Wiyarno (1999) melaporkan hasil penelitiannya bahwa terdapat hubungan yang signifikan antara kejadian toksoplasmosis dengan faktor lingkungan di Surabaya. Faktor lingkungan yang dijadikan variabel penelitian tersebut adalah kebiasaan hidup dan sanitasi lingkungan penduduk Surabaya.

Jenis pekerjaan yang berisiko terinfeksi toksoplasmosis adalah pekerjaan yang berhubungan dengan daging mentah dan tenaga laboran. Dilaporkan bahwa kotoran kucing yang mencemari air, tanah dan pakan babi di peternakan babi Illinois yang di dalamnya juga banyak ditemukan kucing. Hal ini menunjukkan bahwa ookista terdapat pada tinja, tanah, air, dan pakan babi yang ada di lingkungan tersebut. Selain ditemukan adanya ookista tersebut adanya hasil positif toksoplasmosis pada sampel darah dari orang-orang yang mengolah daging babi (92\%), mengolah pakan babi dan kucing 75\% dari 174 pekerja (Weigel et al., 1999). Sidiq, pada tahun 1997, melakukan penelitian serologis Toxoplasma gondii pada ternak babi di RPH Kotamadya Malang. Pada penelitian tersebut ditemukan 23 dari 60 sampel yang diteliti $(38,3 \%)$ positif terinfeksi Toxoplasma gondii.
Kota Surabaya sebagai kota metropolis untuk memenuhi kebutuhan pangan sehari-hari khususnya kebutuhan protein, memerlukan pasokan hewan ternak yang berasal dari luar Surabaya, sebab wilayah Kota Surabaya sendiri tidak memungkinkan untuk dikembangkan pada sektor peternakan. Hewan ternak yang didatangkan dari luar kota tersebut umumnya masih belum diketahui tingkat kesehatannya, kecuali pada hewan ternak yang telah menunjukkan gejala klinis yang jelas.

Berdasarkan Undang-Undang Nomor 13 Tahun 2003 tentang Ketenagakerjaan, maka setiap pekerja mempunyai hak untuk memperoleh: (a) perlindungan atas keselamatan dan kesehatan kerja (b) moral dan kesusilaan (c) perlakuan yang sesuai dengan harkat dan martabat nanusia serta nilai-nilai agama.

Upaya keselamatan dan kesehatan kerja dimaksudkan untuk memberikan jaminan keselamatan dan meningkatkan derajat kesehatan para pekerja/buruh dengan cara pencegahan kecelakaan dan penyakit akibat kerja, pengendalian bahaya ditempat kerja, promosi kesehatan, pengobatan dan rehabilitasi. Bekerja sebagai pejual daging di pasar khususnya yang langsung menangani daging mentah sangat beresiko untuk terinfeksi Toxoplasma gondii dalam bentuk kista jaringan (bradizoit) maupun takizoit.

Diagnosis toksoplasmosis menggunakan uji serologis sering didasarkan pada adanya antibodi terhadap T.gondii. Diagnosis toksoplasmosis menggunakan uji serologis dengan cara deteksi antigen masih jarang dilakukan. Deteksi adanya antigen pada diagnosis toksoplasmosis penting, sebab hewan atau manusia menunjukkan seropositif terhadap antibodi T.gondii belum tentu menderita toksoplasmosis walaupun pernah terinfeksi (Lapin, 1994). Namun, adanya antigen (parasit T.gondii) dapat dilakukan dengan menggunakan hewan coba melalui uji biologi.

Sensitivitas dan spesifisitas alat diagnostik merupakan hal yang perlu diperhatikan dalam diagnostik penyakit. Perkembangan imunologi sebagai ilmu yang mempelajari tentang imunitas atau kekebalan akibat adanya rangsangan molekul asing dalam tubuh hewan atau manusia, baik yang bersifat infeksius maupun non infeksius berkembang pesat akhir-akhir ini (Bharatawidjaja, 2000; Rantam, 2003). 
Enzyme Linked Immunosorbent Assay (ELISA) merupakan salah satu metode serologis yang sensitif (Crowther, 1995; Rantam, 2003; Roit et al., 2001). Crowther (1995) menjelaskan bahwa ELISA lebih sensitif 10 sampai 10.000 kali dibanding metode serologi lain, misalnya Complement Fixation Test atau CFT, hal lain yang dapat ditonjolkan dari ELISA selain sensitivitasnya adalah kemampuan ELISA untuk menangani sampel dalam jumlah besar dan dapat menganalisis hasil dalam waktu yang cepat.

Tingkat kesehatan masyarakat terhadap infeksi Toxoplasmagondii dapat diketahui dari titer antibodi terhadap Toxoplasma gondii penduduknya. Penelitian mengenai hal ini belum dilakukan secara mendalam, terutama pada orang yang mempunyai pekerjaan menangani daging mentah secara langsung, yaitu penjual daging. Penelitian dilakukan untuk mengetahui pola epidemiologi toksoplasmosis pada penjual daging kambing di pasar tradisional Surabaya.

\section{MASALAH PENELITIAN}

Permasalah penelitian ini adalah: Apakah terdapat perbedaan infeksi toksoplasmosis pada penjual daging kambing dan bukan penjual daging, berdasarkan titer IgG positif ?

\section{HIPOTESIS PENELITIAN}

Berdasarkan rumusan masalah dan kajian pustaka yang dilakukan, maka hipotesis dalam penelitian ini adalah : Terdapat perbedaan infeksi toksoplasmosis pada penjual daging kambing dengan bukan penjual daging, berdasarkan titer IgG positif.

\section{METODE PENELITIAN}

\section{Jenis dan Rancangan Penelitian}

Jenis rancangan penelitian yang digunakan adalah studi observasional (expost facto) yang bersifat komparasi. Peneliti tidak memberikan suatu intervensi apapun pada subyek penelitian.

\section{Subyek Penelitian}

Subyek penelitian adalah penjual daging kambing di pasar tradisional Surabaya sebanyak 20 subyek. Penentuan 20 subyek diambil secara acak pada penjual daging kambing yang bersedia untuk diteliti dengan mengisi format lembar persetujuan. Sedangkan untuk kelompok kontrol diambilkan para penjual yang bukan penjual daging di pasar tradisional. Jumlah kontrol diambil sebanyak 20 subyek dengan mengisi lembar persetujuan.

\section{Variabel dan Definisi Operasional Variabel \\ Variabel penelitian}

Variabel dalam penelitian ini adalah: infeksi toksoplasmosis.

Definisi operasional

Infeksi toksoplasmosis adalah masuknya parasit Toxoplasma gondii pada manusia yang ditandai munculnya titer immunoglobulin G (lg.G) positif berdasarkan uji serologi dengan menggunakan teknik indirect sandwich ELISA.

\section{Bahan dan Instrumen Penelitian Bahan untuk uji serologi}

Uji serologi dengan menggunakan teknik indirectsandwich ELISA. Bahan yang digunakan adalah coating buffer, blocking solution, bafer inkubasi, washing buffer, substrate buffer, Phospate Buffered Saline (PBS), akuades, serum darah mencit sebagai antibodi pertama, serum sampel penelitian (meliputi serum penjual daging dan bukan penjual daging) sebagai antigen, serum darah kelinci sebagai antibodi kedua, conjugated goat antihuman lgG alkaline phospatase sebagai anti-immunoglobulin yang dilabel enzim, substrat 4-NPP (ParaNitrophenil Phosphatase), $\mathrm{NaOH} \quad 1 \mathrm{~N}$ sebagai larutan stopper.

\section{Instrumen Penelitian}

Instrumen penelitian yang digunakan untuk uji serologi adalah: sentrifus, eppendorf, plate, alat disinfektan, inkubator, pipet, kertas tisu, ELISA reader.

\section{Lokasi dan Waktu Penelitian}

Lokasi penelitian

Lokasi penelitian di Pasar Tradisional Kotamadya Surabaya yaitu di Pasar Keputran, Pasar Pabean, Pasar Tembok, Pasar Turi, Pasar Pucang.

Waktu penelitian

Penelitian dilakukan selama 3 bulan yaitu bulan Agutus 2011 sampai bulan oktober 2011.

\section{Prosedur Pengambilan atau Pengumpulan Data \\ Pengambilan data penelitian}

Sumber data penelitian atas 2 kelompok yaitu penjual daging kambing (kelompok observasi) dan bukan penjual daging (kelompok kontrol) di pasar tradisional Surabaya. Masing-masing kelompok didatangi oleh peneliti dengan petugas 
medis. Darah diambil pada bagian vena mediana cubiti yang dilakukan oleh petugas medis sebanyak $5 \mathrm{ml}$. Sampel darah selanjutnya dibawa ke Laboratorium Parasitologi FKH Universitas Airlangga Surabaya untuk disentrifus. Darahnya disentrifus pada kecepatan 2500 rpm selama 10 menit, diambil serumnya dan dimasukkan pada dua eppendorf lalu disimpan.

\section{Pelaksanaan indirect sandwich ELISA}

Pemeriksaan serum dengan menggunakan teknik indirect sandwich ELISA dilakukan di Laboratorium Parasitologi $\mathrm{FKH}$ Universitas Airlangga Surabaya. Prinsip kerja indirect sandwich ELISA adalah melapiskan antigen ke lubang mikroplate (well) kemudian direaksi dengan antibodi pertama dan selanjutnya direaksikan dengan antibodi kedua (conjugate fragment immunoglobulin G) kemudian divisualisasikan dengan substrat peroksida atau alkaline fosfat.

Cara kerja indirect sandwich ELISA secara rinci melalui prosedur sebagai berikut: menyiapkan plate ELISA yang terdiri 96 sumuran, diberi $100 \mu$ lantigen (konsentrasi 10 $\mu \mathrm{l} / \mathrm{ml}$ ) kemudian diinkubasi pada suhu $37^{\circ} \mathrm{C}$ selama satu malam. Selanjutnya dicuci dengan washing buffer sebanyak 3 kali dengan volume $250 \mu \mathrm{l}$ setiap plate dan ditambahkan $200 \mu \mathrm{l}$ blocking solution (BSA) $1 \%$ atau creamer $4 \%$ dan diinkubasi pada suhu $37^{\circ} \mathrm{C}$ selama 1 jam. Kemudian dicuci dengan washing buffer sebanyak 3 kali dengan volume $250 \mu$ l setiap plate, lalu ditambahkan serum sampel sebanyak $100 \mu \mathrm{l}$ (sebagai antibodi I) dan diinkubasi pada suhu $37^{\circ} \mathrm{C}$ selama 1 jam. Selanjutnya dicuci dengan washing buffer sebanyak 3 kali dengan volume $250 \mu \mathrm{l}$ setiap plate, kemudian ditambahkan konjugat (sebagai antibodi II) sebanyak $100 \mu \mathrm{l}$ dan diinkubasi pada suhu $37^{\circ} \mathrm{C}$ selama 1 jam. Selanjutnya dicuci lagi dengan washing buffer sebanyak 3 kali dengan volume $250 \mu \mathrm{l}$ setiap plate, lalu ditambahkan substrat sebanyak $150 \mu \mathrm{l}$ selama 5-15 menit. Kemudian reaksi dihentikan dengan menambahkan $\mathrm{NaOH}$ $1 \mathrm{~N}$ sebanyak $50 \mu$ l, lalu pembacaan hasil dengan menggunakan ELISA reader.

\section{Analisis Data}

Data yang terkumpul akan dibuat tabulasi data secara manual, yang selanjutnya data tersebut akan diuji dengan menggunakan statistik SPSS for windows. Rumus statistik yang digunakan dalam analisis data pada penelitian ini adalah uji chi-square. Uji chi-square digunakan untuk menganalisis perbedaan proporsi toksoplasmosis pada penjual daging kambing dengan bukan penjual daging kambing sebagai kontrol.

\section{HASIL DAN PEMBAHASAN \\ Hasil \\ Karakteristik subyek penelitian.}

Karakteristik subyek penelitian dijabarkan pada jenis kelamin,usia, pendidikan, etnis, dan lama bekerja.

\section{Jenis kelaminsubyek penelitian}

Jenis kelamin subyek penelitian pada penjual daging dan bukan penjual dagingterlihat pada tabel 1. Jenis kelamin kelompok ini adalah lakilaki yaitu $70 \%$ dan perempuan $30 \%$.

Tabel 1 Jenis kelamin subyek penelitian

\begin{tabular}{|c|c|c|c|c|c|c|}
\hline Jenis & \multicolumn{2}{|c|}{ Penjual } & \multicolumn{2}{|c|}{$\neq$ Penjual } & \multicolumn{2}{|c|}{ Total } \\
\cline { 2 - 7 } kelamin & $\mathrm{n}$ & $\%$ & $\mathrm{n}$ & $\%$ & $\mathrm{n}$ & $\%$ \\
\hline Laki-laki & 15 & 75 & 13 & 65 & 28 & 70 \\
Peremp. & 5 & 25 & 7 & 35 & 12 & 30 \\
\hline Jumlah & 20 & 100 & 20 & 100 & 40 & 100 \\
\hline
\end{tabular}

\section{Usia subyek penelitian.}

Usia subyek penelitian bervariasai mulai dari usia 15 tahun hingga 61 tahun. Subyek penelitian terbanyak berusia 41-50 tahun yaitu sebanyak $60 \%$, sedangkan kelompok usia sedikit pada kelompok usia $\leq 30$ tahun. Distribusi usia subyek penelitian dapat dilihat pada tabel berikut ini.

Tabel 2 Usia subyek penelitian

\begin{tabular}{|c|c|c|c|c|c|c|}
\hline \multirow{2}{*}{$\begin{array}{c}\text { Usia } \\
\text { (tahun) }\end{array}$} & \multicolumn{2}{|c|}{ Penjual } & \multicolumn{2}{|c|}{$\neq$ Penjual } & \multicolumn{2}{|c|}{ Total } \\
\hline & $n$ & $\%$ & $\mathrm{n}$ & $\%$ & $\mathrm{n}$ & $\%$ \\
\hline$\leq 30$ & 2 & 1 & & 0 & 2 & 5 \\
\hline $31-4$ & 3 & 15 & 2 & 10 & 5 & 12,5 \\
\hline $41-50$ & 11 & 55 & 13 & 65 & 24 & 60 \\
\hline$\geq$ & 4 & 20 & 5 & 25 & 9 & 22,5 \\
\hline Jumlah & 20 & 100 & 20 & 100 & 40 & 100 \\
\hline
\end{tabular}

\section{Tingkat pendidikan subyek penelitian.}

Tingkat pendidikan formal bervariasi dari masingmasing kelompok subyek penelitian. Pada kelompok pendidikan $\geq$ TmSMAmerupakan kelompok terbanyak, sedangkan kelompok sedikit adalah dengan tingkat pendidikan Tamat SD dan Tidak Tamat SD. Tingkat pendidikan formal subyek penelitian dapat dilihat pada Tabel 3 sebagai berikut. 
Tabel 3 Tingkat pendidikan subyek penelitian

\begin{tabular}{|c|c|c|c|c|c|c|}
\hline \multirow{2}{*}{$\begin{array}{c}\text { Pendi } \\
\text { dikan }\end{array}$} & \multicolumn{2}{|c|}{ Penjual } & \multicolumn{2}{|c|}{$\neq$ Penjual } & \multicolumn{2}{|c|}{ Total } \\
\cline { 2 - 7 } & $\mathrm{n}$ & $\%$ & $\mathrm{n}$ & $\%$ & $\mathrm{n}$ & $\%$ \\
\hline T.Tm SD & 2 & 10 & 0 & 0 & 2 & 5 \\
Tm SD & 2 & 10 & 0 & 0 & 2 & 5 \\
Tm SMP & 9 & 45 & 2 & 10 & 11 & 27,5 \\
$\geq$ TmSMA & 7 & 35 & 18 & 90 & 25 & 62,5 \\
\hline Jumlah & 20 & 100 & 20 & 100 & 40 & 100 \\
\hline
\end{tabular}

\section{Etnissubyek penelitian}

Etnis subyek penelitian yang terlibat dalam penelitian hanya terdiri atas dua yaitu Madura dan Jawa. Jumlah dari ke dua etnis hampir seimbang yaitu etnis Jawa $47,5 \%$ sedangkan etnis Madura 52,5\%. Distribusi etnis subyek penelitian dapat dilihat pada tabel dan Tabel 4 berikut ini.

Tabel 4 Etnis subyek penelitian

\begin{tabular}{|c|c|c|c|c|c|c|}
\hline \multirow{2}{*}{ Etnis } & \multicolumn{2}{|c|}{ Penjual } & \multicolumn{2}{|c|}{$\neq$ Penjual } & \multicolumn{2}{|c|}{ Total } \\
\cline { 2 - 7 } & $\mathrm{n}$ & $\%$ & $\mathrm{n}$ & $\%$ & $\mathrm{n}$ & $\%$ \\
\hline Jawa & 4 & 20 & 15 & 75 & 19 & 47,5 \\
Madura & 16 & 80 & 5 & 25 & 21 & 52,5 \\
\hline Jumlah & 20 & 100 & 20 & 100 & 40 & 100 \\
\hline
\end{tabular}

\section{Lama bekerja subyek penelitian}

Lama bekerja subyek penelitian dibedakan 3 kelompok yaitu kurang dari 5 tahun, 5 sampai 10 tahun dan di atas 10 tahun. Apabila dilihat dari lama bekerja, umumnya subyek penelitian mempunyai lama kerja 5-10 tahun. Distribusi lama bekerja subyek penelitian dapat dilihat pada Tabel 5 sebagai berikut.

Tabel 5 Lama bekerja subyek penelitian

\begin{tabular}{|c|c|c|c|c|c|c|}
\hline \multirow{2}{*}{ Lama } & \multicolumn{2}{|c|}{ Penjual } & \multicolumn{2}{|c|}{$\neq$ Penjual } & \multicolumn{2}{|c|}{ Total } \\
\cline { 2 - 7 } bekerja & $\mathrm{n}$ & $\%$ & $\mathrm{n}$ & $\%$ & $\mathrm{n}$ & $\%$ \\
\hline$<5$ th & 3 & 15 & 2 & 10 & 5 & 12,5 \\
$5-10$ th & 11 & 55 & 11 & 55 & 22 & 55 \\
$>10$ th & 6 & 30 & 7 & 35 & 13 & 32.5 \\
\hline Jumlah & 20 & 100 & 20 & 100 & 70 & 100 \\
\hline
\end{tabular}

\section{Pemeriksaan titer}

Hasil pemeriksaan serum subyek penelitian terhadap titer IgG, secara lengkap dapat dilihat pada tabel 6 sebagai berikut.

Tabel 6 Hasil pemeriksaan titer antibodi IgG terhadap T.gondii

\begin{tabular}{|c|c|c|c|c|}
\hline $\begin{array}{l}\text { Kode } \\
\text { Serum }\end{array}$ & $\begin{array}{c}\text { Titer } \\
\text { Ig.G }\end{array}$ & Hasil & Pekerjaan & $\begin{array}{c}\text { Cut } \\
\text { of } \\
\text { point }\end{array}$ \\
\hline 1 & 1.357 & + & $\neq$ Penjual & IgG $=$ \\
\hline
\end{tabular}

\begin{tabular}{|c|c|c|c|c|}
\hline 2 & 0.882 & + & $\neq$ Penjual & \multirow[t]{3}{*}{0.513} \\
\hline 3 & 0.510 & - & $\neq$ Penjual & \\
\hline 4 & 0.456 & - & $\neq$ Penjual & \\
\hline 5 & 1.056 & + & $\neq$ Penjual & \\
\hline 6 & 0.398 & - & $\neq$ Penjual & \\
\hline 7 & 1.187 & + & $\neq$ Penjual & \\
\hline 8 & 1.271 & + & $\neq$ Penjual & \\
\hline 9 & 0.496 & - & $\neq$ Penjual & \\
\hline 10 & 0.509 & - & $\neq$ Penjual & \\
\hline 11 & 0.437 & - & $\neq$ Penjual & \\
\hline 12 & 0.770 & + & $\neq$ Penjual & \\
\hline 13 & 0.430 & - & $\neq$ Penjual & \\
\hline 14 & 1.226 & + & $\neq$ Penjual & \\
\hline 15 & 0.496 & - & $\neq$ Penjual & \\
\hline 16 & 0.322 & - & $\neq$ Penjual & \\
\hline 17 & 0.270 & - & $\neq$ Penjual & \\
\hline 18 & 0.763 & + & $\neq$ Penjual & \\
\hline 19 & 0.275 & - & $\neq$ Penjual & \\
\hline 20 & 0.671 & + & $\neq$ Penjual & \\
\hline 21 & 0.551 & + & Penjual & \\
\hline 22 & 0.692 & + & Penjual & \\
\hline 23 & 0.745 & + & Penjual & \\
\hline 24 & 1.014 & + & Penjual & \\
\hline 25 & 1.127 & + & Penjual & \\
\hline 26 & 0.364 & - & Penjual & \\
\hline 27 & 0.303 & - & Penjual & \\
\hline 28 & 0.669 & + & Penjual & \\
\hline 29 & 0.273 & - & Penjual & \\
\hline 30 & 0.673 & + & Penjual & \\
\hline 31 & 0.951 & + & Penjual & \\
\hline 32 & 0.639 & + & Penjual & \\
\hline 33 & 0.711 & + & Penjual & \\
\hline 34 & 0.914 & + & Penjual & \\
\hline 35 & 0.813 & + & Penjual & \\
\hline 36 & 0.380 & - & Penjual & \\
\hline 37 & 1.536 & + & Penjual & \\
\hline 38 & 1.529 & + & Penjual & \\
\hline 39 & 0.803 & + & Penjual & \\
\hline 40 & 1.362 & + & Penjual & \\
\hline
\end{tabular}

\section{Analisis hasil dan uji hipotesis}

Berdasarkan hasil analisis data dengan menggunakan statistik SPSS for windows, rumuschi-squaredidapatkan hasil p.0.022. (lihat lampiran 3). Jika hasil signifikansi ini dibandingkan dengan signifikansi kritis $5 \%$ yaitu 0,05 maka di dapatkan 0,022 <0,05 (signifikan).

Oleh karena itu hipotesis pada: Terdapat perbedaan infeksi toksoplasmosis pada penjual daging kambing dengan bukan penjual daging, berdasarkan titer IgG positif, dapat diterima. 


\section{Pembahasan \\ Karakteristik Subyek penelitian.}

Secara rinci karakteristik subyek penelitian dapat dijelaskan sebagai berikut.

\section{Jenis kelamin}

Jika dilihat dari jenis kelamin subyek penelitian, maka subyek penelitian laki-laki $70 \%$, dan subyek penelitian perempuan $30 \%$.

Berdasarkan penelitian Chiou et al., (2002) didapatkan bahwa jenis kelamin tidak berhubungan dengan prevalensi toksoplasmosis. Penelitian Chiou tersebut dengan memeriksa penduduk dua daerah pegunungan di Taiwan. Dua daerah pegunungan tersebut adalah pegunungan di Negara Taiwan dan pegunungan di Asia Tenggara. Penelitian dilakukan mulai dari bulan Pebruari 1998 sampai bulan Juli 2000, dengan menggunakan latex aglutination test. Hasil penelitian didapatkan tidak ada perbedaan jenis kelamin terhadap seroprevalensi toxoplasmosis. (Chiou, et al., 2002).

\section{Usia}

Usia subyek penelitian bervariasai mulai dari usia 15 tahun hingga 61 . Secara spesifik usia tidak menjadi variabel utama dalam penelitian ini, namun di beberapa penelitian lain menyatakan usia cukup perpengaruh terhadap kejadian infeksi toksoplasmosis.

Jones et al., (2005) menyatakan bahwa faktor usia merupakan faktor resiko yang penting dalam epidemiologi toksoplasmosis. Penelitian Jones mengambil sampel anak-anak pedesaan di Guatemala pada tahun 1999, dan ditemukan $66(12,4 \%)$ positif toksoplasmosis berdasarkan titer IgG dari 532 anak yang berusia 6 bulan sampai 2 tahun. Penelitian yang sama dilakukan pada tahun 2003 terhadap 500 anak usia 3 tahun sampai 10 tahun, didapatkan prevalensi toksoplasmosis $24 \%$ sampai $43 \%$. Penelitian tersebut menyimpulkan bahwa semakin banyak umur prevalensi toksoplasmosis semakin besar (Jones et al., 2005). Beberapa penelitian menjelaskan banyaknya usia berpengaruh terhadap prevalensi toksoplasmosis (Estevez et al., 2001; Ertug et al., 2005).

\section{Pendidikan}

Tingkat pendidikan subyek penelitian dibedakan tidak tamat SD, tamat SD, tamat SMP dan tamat SMA. Beberapa penelitian dengan menggunakan tingkat pendidikan, status kependudukan, riwayat keguguran, konsumsi daging, jenis makanan, kesehatan pribadi dan pemeliharaan kucing sebagai faktor resiko terhadap prevalensi toksoplasmosis. Penelitian dengan menggunakan sampel wanita hamil sebanyak 423 dan pemeriksaan serum menggunakan ELISA kelas IgG. Hasil penelitian menyimpulkan bahwa faktor resiko tidak berpengaruh terhadap prevalensi toksoplasmosis (Fernandez et al., 2001; Ertug et al., 2005).

\section{Etnis}

Terdapat dua kelompok etnis pada penelitian ini yaitu etnis Jawa dan etnis Madura. Hasil pemeriksaan titer IgG untuk etnis Jawa besar proporsi toksoplasmosis $66,7 \%$ dan etnis Madura 75. Penelitian yang dilakukan di Thailand dengan membandingkan seroprevalensi toksoplasmosis pada tiga kelompok etnis yaitu etnis Akka, Yau, dan Han. Penelitian dilakukan selama bulan Januari 2003 dan pemeriksaan serum dilakukan dengan menggunakan LAT. Penelitian ini menyimpulkan bahwa perbedaan etnis tidak berpengaruh terhadap prevalensi toksoplasmosis (Han et al., 2003).

\section{Lama bekerja.}

Pemeriksaantoksoplasmosis berdasarkan titer IgG pada subyek penelitian yang mempunyai lama bekerja kurang dari 5 tahun didapatkan proporsi sebesar 66,7\%, lama bekerja 5-10 tahun 73,7\%, dan lama bekerja lebih dari 10 tahun $69,6 \%$.

Lama bekerja dengan pekerjaan sebagai penjual daging kambing mempunyai resiko yang tinggi untuk terinfeksi Toxoplasma, karena mendapatkan paparan secara terus-menerus selama bekerja. Bekerja sebagai penjual daging menarik bagi peneliti untuk diketahui tingkat prevalensinya. Penelitian yang dilakukan di kota Jeddah, Arab Saudi dengan mengambil sampel domba, kambing, dan pemotong kambing. Hasil penelitian didapatkan prevalensi toksoplasmosis pada pengukuran IgG domba 39\%, kambing $28 \%$, sedangkan pada pemotong kambing diperoleh prevalensi $80 \%$ positif toksoplasmosis IgG dan $20 \%$ positif toksoplasmosis IgM (Morsy et al., 1997).

\section{Perbedaan infeksi Toksoplasmosis pada penjual daging kambing dan bukan penjual dagingberdasarkan titer IgG positif.}

Hasil uji hipotesis penelitian ini menjelaskan bahwa terdapat perbedaan infeksi 
toksoplasmosis antara penjual daging kambing dengan bukan penjual daging berdasarkan titer lg.G positif di pasar tradisional Surabaya.

Diterimanya hipotesis tersebut, mengindikasikan bahwa jenis pekerjaan yang memungkinkan kontak langsung dengan daging kambing mempunyai risiko lebih besar dibandingkan dengan pekerjaan yang tidak kontak langsung dengan daging.

Freire et al., (2005) mengadakan penelitian seroprevalensi terhadap T.gondii pada pekerja yang menangani daging dan pekerja pemotong (jagal) di Londrina Brazil. Hasil penelitian didapatkan dari 36 pekerja yang menangani daging mentah positif toksoplasmosis 20 pekerja (55.5\%), sedangkan pada 11 pemotong (jagal) positif toksoplasmosis 8 orang (72,7\%).

Penelitian

seroepidemiologi

toksoplasmosis orang keturunan Amerika-Indian di Barat Venezuela. Penelitian dilakukan dengan mengambil sampel yang tinggal di tiga lokasi daerah pegunungan dan yang tinggal di satu daerah dataran rendah dengan usia mulai dari 1 tahun hingga 69 tahun. Serum sampel yang diperiksa antibodi Ig.G terhadap Toxoplasma dengan menggunakan metode IHAT yang ada di pasaran. Hasil penelitian secara menyeluruh didapatkan 222 (49.7\%) dari 447 positif toksoplasmosis. Penduduk yang tinggal di daerah dataran rendah mempunyai seroprevalensi toksoplasmosis lebih tinggi dibandingkan dengan penduduk yang tinggal di daerah pegunungan. Ada peningkatan seroprevalensi seiring dengan peningkatan usia sampel yang diperiksa (Estevez et al., 2001). Jika dibandingkan tingkat prevalensi pada penjual daging kambing di Surabaya, yang besarnya prevalensi mencapai $85 \%$, maka tingkat prevalensi di Venezuela masih relatif rendah.

Perbandingan yang lain adalah tingkat prevalensi toksoplasmosis pada daerah yang dekat dengan Kota Surabaya adalah Kota Sidoarjo. Penelitian di Kota Sidoarjo tersebut menemukan seroepidemiologi terhadap lima penyakit infeksi yaitu Toxoplasma gondii, Entamoeba histolytica, Toxocara canis, Angiostrongylus cantonensis dan Anisakis species. Subyek penelitian adalah pasien yang berkunjung ke rumah sakit Kota Sidoarjo dari bulan Mei 1992 sampai bulan Oktober 1993. Sampel yang didapatkan 244 dengan pemeriksaan masing-masing menggunakan test enzyme linked immunosorbent assay (ELISA), latex agglutination (LA) test, indirect fluorescence antibody (IFA) test, hemagglutination (HA) test dan gel didiffusion precipitation (GDP) test. Hasil penelitian seropositif didapatkan Toxoplasma gondii 64\%, Entamoeba histolytica 2-15\%, Toxocara canis 63\%, Angiostrongylus cantonensis $17 \%$ dan Anisakis species 11\% (Hasan et al., 1996). Penelitian dari Sidoarjo ini memperlihatkan bahwa prevalensi T.gondii paling tinggi di antara penyakit infeksi lain yang diteliti, tetapi jika dibandingkan dengan prevalensi pada penjual daging kambing di Surabaya, prevalensi di Sidoarjo tersebut masih lebih rendah.

\section{SIMPULAN DAN SARAN}

Studi seroepidemiologi toksoplasmosis telah dilakukan pada penjual daging kambing dan bukan penjual daging di pasar tradisional Surabaya pada tahun 2011, memberikan kesimpulan : terdapat perbedaan infeksi toksoplasmosis antara penjual daging kambing dengan bukan penjual daging berdasarkan titer Ig.G positif di pasar tradisional Surabaya.

Saran:

1. Perlu dilakukan peningkatan kesehatan dan keselamatan kerja di tempat pada penjual daging kambing dengan menggunakan APD (Alat Pelindung Diri) dan berperilaku sehat agar infeksi Toxoplasma yang terdapat pada daging kambing dapat dicegah.

2. Perlu dilakukan perbaikan sarana yang terdapat di pasar tradisional Surabaya seperti tersedianya air bersih yang cukup, tempat sampah, cahaya dan ventilasi yang cukup.

3. Perlu dilakukan penyuluhan terhadap masyarakat agar berhati-hati jika kontak maupun mengolah daging kambing.

\section{DAFTAR ACUAN}

Bharatawidjaja KG, 2000, Immunologi Dasar. Edisi Keempat, Penerbit Balai, Fakultas Kedokteran Universitas Indonesia, Jakarta.

Chiou HY, Fan CK, Su KE, Wu GH, 2002, Seroepidemiology of Toxoplasma gondii infection among two mountain aboriginal populations and Southeas Asian laborers in Taiwan, Departement of Parasitology, College of Medicine, Taipei Medical University, Taiwan, Republic of China. 
tedfan@tmu.edu.tw. J. Parasitol. 88(2):411-4

Crowter JR, 1995, Methods in Moleculer Biology. ELISA Theory and Practice. Vol.42. Human Press. Totowa, New Jersy

Dachlan EG, 2006, Toksoplasmosis, Pencegahan dan Penanggulangannya pada lbu Hamil, Kumpulan Makalah Seminar, FKH Universitas Airlangga, Surabaya

Dubey JP, 1999. Toxoplasma gondii. Available on http://www.medimicrochapter 84.htm/ diakses 21 Januari 2006

Ertug S, Okvav P, Turkmen M, Yuksel H, 2005, Seroprevalence and risk factors for Toxoplasma infection among pregnant women in Aydin province, Turkey, BMC Public Health. 5(1):66-8

Estevez J, Chacin-Bonilla L, Sanchez-Chavez Y, Monsalve F, 2001, Seroepidemiology of toxoplasmosis in amerindians from western Venezuela, Instituto de Investigaciones Clinicas, Universidad del Zulia, Maracaibo, Venezuela. ebonilla@reacciun.veAm.J. Trop. Med. Hyg. 65(2): 131-5

Fernandez M, Diaz-Suarez O, Parra AM, 2001, Seroepidemiology of toxoplasmosis in a marginal community of the Municipality of Maracaibo, Zulia State, Venezuela, Invest. Clin. 42(2):107-21

Freire RL, Dias RA, Navarro IT, Ruffolo BB, Bugni FM, Castro MV, 2005, Toxoplasma gondii in fresh pork sausage and seroprevalence in butchers from factories in Londrina, Parana State, Brazil, Rev Inst Med, Trop Sao Paolo. 47(4):185-9.

Frenkel J.K, 1990, Toxoplasmosis in Human Beings, JAVMA, 196: 240-248

Han BC, Fan CK, Liao CW, Wu MS, Su KE, 2003, Seroepidemiology of Toxoplasmagondii in infection among Chinese aboriginal and Han people residing in mountainous areas of northern Thailand, J. Parasitol. 89(6):1239-42.
Hasan H, Uga S, Ono K, Kataoka N, 1996, Seroepidemiology of five major zoonotic parasite infections in inhabitants of Sidoarjo, East Java, Indonesia, Southeast Asian J. Trop. Med. Publich Health, ;27(3):556-61

Jones JL, Lopez B, Alvarez MM, Wilson M, Klein $\mathrm{R}$, Luby S, Maguire $\mathrm{JH}, 2005$, Toxoplasma gondii infection in rural Guatemalan children, Am. J. Trop. Med. Hyg. 72(3):295300

Lappin MR, 1994, Feline Toxoplasmosis, Welthom Focus. 4(4):2-8

Mc Cabe RE and Remington JS, 1995, Toxoplasma gondii in : Principles and Practice in Infectius Diseases. $2^{\text {nd }}$. Ed Mandel GL; Dauglas RG andBennet JE (eds) Churchill Livingstone. New York.

Morsy TA, Amin AM, 1997, Anti-Toxoplasma antibodies in butchers and slaughtered sheep and goats in Jeddah Municipal abattoir, Saudi Arabia. J. Egypt. Soc. Parasitol. 27(3):913-8

Rantam, F.A. 2003. Metode Imunologi. Cetakan Pertama. Airlangga University Press. Surabaya. 79-122

Retnowulan, D. 2004. Prevalensi Toksoplasmosis Pada Kambing dan Domba di Rumah Potong Hewan Pegirian Kota Surabaya Menggunakan Uji Dot Blot. Skripsi. Fakultas Kedokteran Hewan. Universitas Airlangga.

Roit I, J.Brostoff and D.Male. 2001. Immunology. $6^{\text {th }}$. Ed.Mosby. Spain.

Sasmita R, 1991, Infeksi Toxoplasma gondii Isolat Surabaya : Beberapa Aspek Serologis, Gambaran Darah Dan Hispatologis Mencit (Mus Musculus). Disertasi, UNAIR Surabaya

Sasmita R, 1993, Sigi Prevalensi Antibodi Toxoplasma Pada Kambing di Tuban dan Kediri, Jawa Timur, Bull. IPKHI. 3:11-20

Sciammarella J, 2001. Toxoplasmosis, Medicine Journal. 2(9):1-10. 
Shulman, S., G Koren., Boskovic., T.R.Einarson., O.P.Soldin, and A.Einarson. 1994, Seroprevalensi of Toxoplasma gondii infection on Toronto, Ontario, Canada.J.Parasitol. 15:85-94

Sidiq M, 1997, Sigi Serologis Toxoplasmosis pada Babi di RPH Kotamadya Malang, Skripsi, Fakultas Kedokteran Hewan, Universitas Airlangga, Surabaya

Smith JE and Rebuck N, 2000. Toxoplasma gondii Strain Variation and Phatogenecity. In. Microbial Foodborne disease. Cary JW, JE linz and D. Bhatnagar (Eds). Technomic Co. Inc. USA. P. (25):405-431

Soedarto, 1992, Penyakit-Penyakit Infeksi di Indonesia, Widya Medika, Jakarta

Weigel RM, Dubey JP, Dyer D and Siegel AM, 1999. Risk Factors of Infection with Toxoplasma gondii for Residents and Workers on Swine Farms in Illinois. Am. J. Trop. Med. Hyg. 60(5). p.793-798

Wiyarno Y, 1999. Hubungan antara kejadian toksoplasmosis dengan faktor lingkungan di Surabaya, Thesis, Pascasarjana Unair Surabaya. 